\title{
Adrenomedullin expression and function in the rat carotid body
}

\author{
A Martínez, L Saldise ${ }^{1}$, M J Ramírez ${ }^{2}$, S Belzunegui ${ }^{1}$, E Zudaire, \\ M R Luquin ${ }^{1}$ and F Cuttitta
}

Cell and Cancer Biology Branch, National Cancer Institute, National Institutes of Health, Building 10, Room 13N262, Bethesda, Maryland 20892, USA

${ }^{1}$ Department of Experimental Neurology, University of Navarra, 31080 Pamplona, Spain

${ }^{2}$ Department of Pharmacology, University of Navarra, 31080 Pamplona, Spain

(Requests for offprints should be addressed to A Martínez; Email: martineza@mail.nih.gov)

\begin{abstract}
Adrenomedullin (AM) immunoreactivity has been found in granules of the glomus (type I) cells of the carotid bodies in rats. The identity of these cells was ascertained by colocalization of immunoreactivities for AM and tyrosine hydroxylase in their cytoplasm. Exposure of freshly isolated carotid bodies to synthetic AM resulted in a concentration- and time-dependent degranulation of glomus cells as measured by dopamine (DA) release. DA release reached a zenith $30 \mathrm{~min}$ after exposure to AM (94.2\% over untreated controls). At this time-point, the response to AM was similar to the one elicited by $5 \mathrm{~min}$ of exposure to $100 \mathrm{mM} \mathrm{K}^{+}$. Nevertheless, injection of $1 \mu \mathrm{l}$
\end{abstract}

$60 \mathrm{nM} \mathrm{AM} / \mathrm{g}$ body weight into the tail vein of the rats did not induce statistical differences in DA release from the carotid bodies. Exposure of the oxygen-sensitive cell line PC-12 to hypoxia elicited an increase in AM mRNA expression and peptide secretion into serum-free conditioned medium. Previous data have shown that elevation of AM expression under hypoxia is mediated through hypoxia-inducible factor-1, and that exposure of chromaffin cells to AM results in degranulation. All these data suggest that $A M$ is an important autocrine regulator of carotid body function.

Journal of Endocrinology (2003) 176, 95-102

\section{Introduction}

Adrenomedullin (AM) is a 52 amino acid peptide containing an internal disulfide bond and a C-terminal amide group. It was originally isolated from a pheochromocytoma and shown to elevate cAMP in platelets (Kitamura et al. 1993). Many functions have been ascribed to AM. This peptide can act as a vasodilator, bronchodilator, growth factor, regulator of hormone secretion, neurotransmitter, antimicrobial agent, and a controller of renal function, among others (Hinson et al. 2000, López \& Martínez 2002).

The most characteristic activity of AM is the induction of an intensive, long-lasting dose-dependent hypotension in humans, rats, rabbits, dogs, cats, and sheep. AM dilates resistance and capacitance vessels in the kidneys, heart, brain, lung, hindlimbs, and mesentery. Moreover, AM elicits relaxation of ring preparations of the aorta and cerebral arteries. An intravenous injection of human AM to conscious sheep causes a dose-dependent fall of blood pressure, an increase in heart rate and cardiac output with a small reduction in stroke volume, as well as a marked decrease in total peripheral resistance (Parkes 1995). In human coronary arteries, AM elicits vasodilatation through specific AM receptors and by enhancing production of nitric oxide (Terata et al. 2000). AM levels increase under pathological conditions such as heart failure, myocardial infarction, hypertension, and septic shock (Eto et al. 1999). Conversely, intracerebroventricular administration of AM induces hypertension and tachycardia in conscious rats (Saita et al. 1998). In addition, when microinjected into the area postrema, AM increases blood pressure and heart rate (Mark et al. 1997). These observations thus indicate that AM influences blood pressure in a differential manner depending on the site of action.

Carotid bodies are a small pair of highly vascularized and well-perfused organs located at each carotid artery bifurcation. They are sensory organs that detect decreases in arterial blood oxygen and react by stimulating the nucleus tractus solitarius in the brain stem. This nucleus can precipitate a wide array of systemic reflex responses, including ventilatory and cardiovascular acclimatization. A bulk of evidence suggests that glomus (type I) cells are the initial site of transduction and that they release transmitters in response to hypoxia, which in turn cause depolarization of nearby afferent nerve endings. Acute hypoxia causes a rapid response within milliseconds, which is mediated by oxygen-sensitive $\mathrm{K}^{+}$channels located in the glomus cell membrane. On the other hand, responses to chronic hypoxia are much slower and include changes in gene expression profiles that are responsible for the phenotypic changes observed in pathophysiological situations such as 
sleep apneas, apneas in premature infants, asthma, or pulmonary fibrosis. Some of these hypoxia-induced changes in gene expression include elevation in the levels of dopamine (DA), norepinephrine, nitric oxide, and endothelin, and a decrease in the levels of substance $\mathrm{P}$ (López-Barneo et al. 2001, Prabhakar et al. 2001).

AM is expressed by chromaffin cells of the adrenal medulla (Kapas et al. 1998), which share a common embryonic origin with glomus cells and have similar mechanisms of oxygen sensing and response (Millhorn et al. 1996) and are often used as physiological models for carotid body studies. AM expression is upregulated under hypoxic conditions through hypoxia-inducible factor-1 (HIF-1) (Garayoa et al. 2000) and has been found in many structures of the central nervous system (Serrano et al. 2000). In addition, exposure of the rat brain to ischemia reperfusion results in a dramatic increase in AM expression in both neural and vascular structures of the brain (Serrano et al. 2001). Based on these facts we decided to study whether AM is expressed in the carotid body and, if so, whether it influences carotid body physiology.

\section{Materials and Methods}

\section{Animals and surgical procedure}

Experiments were performed using carotid bodies from adult male Wistar rats (body weight (BW) 240-280 g) which were housed under standard conditions of $50 \%$ humidity, 16 liters/min air exchange, and a $12 \mathrm{~h}$ light: $12 \mathrm{~h}$ darkness cycle, with food and water provided ad libitum. Animals were anesthetized by intraperitoneal injection of $80 \mathrm{mg} / \mathrm{kg}$ ketamine (Ketolar; Park-Davis, Madrid, Spain) and $10 \mathrm{mg} / \mathrm{kg}$ xylaxine (Rompum; Bayer, Madrid, Spain). Carotid bodies were removed from the carotid bifurcation, cleaned of surrounding connective tissue and either fixed for immunodetection (see below) or treated as indicated and kept frozen at $-80{ }^{\circ} \mathrm{C}$ until extracted. All procedures were approved by the animal ethics committee of the University of Navarra.

\section{Double immunofluorescence and confocal microscopy}

Carotid bodies from four animals were fixed in $4 \%$ paraformaldehyde for $30 \mathrm{~min}$, embedded in OCT compound (Tissue-Tek; Miles Inc., Elkhart, IN, USA) and frozen in liquid nitrogen. Sections $(20 \mu \mathrm{m}$ thick) were blocked with a mixture of 3\% donkey and 3\% goat normal sera (Jackson Immunoresearch Labs, West Grove, PA, USA) and then exposed to a mixture of two primary antibodies obtained from different species, overnight at $4{ }^{\circ} \mathrm{C}$. The mixture consisted of a previously characterized rabbit antibody against AM (Martínez et al. 1995) and a monoclonal mouse antibody against tyrosine hydroxylase (Chemicon, Temecula, CA, USA), both at a final concentration of 1:1000. The next day, the sections were incubated for $1 \mathrm{~h}$ with a mixture of Bodipy-goat antirabbit (Molecular Probes, Eugene, OR, USA), and Texas red-donkey anti-mouse (Jackson Immunoresearch Labs), both at a final concentration of 1:200. Counterstaining with DAPI (Molecular Probes) was performed for $10 \mathrm{~min}$. After thorough washes, the slides were mounted in GelMount (Biomeda, Foster City, CA, USA) and observed with a Zeiss laser scanning microscope 510, equipped with four lasers.

\section{Analysis of $\mathrm{DA}$ secretion}

Freshly isolated carotid bodies (12-16 per treatment) were incubated with synthetic AM (Peninsula Labs, San Carlos, CA, USA) in a time-course $(5-60 \mathrm{~min})$ and a doseresponse $\left(10^{-8}\right.$ to $\left.10^{-5} \mathrm{M}\right)$ manner. Individual carotid bodies were immersed in $100 \mu \mathrm{l} 0 \cdot 4 \mathrm{M}$ perchloric acid, $1 \mathrm{mM}$ EDTA, and $0 \cdot 1 \%$ sodium metabisulfite and vortexed for $1 \mathrm{~min}$ to extract DA as described (VerbieseGenard et al. 1983). DA contents in the extraction samples $(20 \mu \mathrm{l})$ were determined using high-performance liquid chromatography with electrochemical detection as previously reported (Kilts et al. 1981). The mobile phase composition was $0.1 \mathrm{mM} \mathrm{Na} \mathrm{HPO}_{4}, 0.1 \mathrm{M}$ citric acid, $0.74 \mathrm{mM}$ octansulphonic acid, $1 \mathrm{mM}$ EDTA, and $14 \%$ methanol, pH 3.4. DA contents were calculated by extrapolation against a standard curve $(125-500 \mathrm{pg} / 20 \mu \mathrm{l}$ DA). A group of 12 carotid bodies was incubated with $100 \mathrm{mM} \mathrm{KCl}$ for $5 \mathrm{~min}$, to check the validity of our experimental procedure by studying the response of the preparation to a well-known depolarizing stimulus (Rosenbland \& Nilsson 1993). Different sets of samples were used for each incubation time.

For the in vivo study, 18 animals received $1 \mu \mathrm{l} 60 \mathrm{nM}$ $\mathrm{AM} / \mathrm{g} \mathrm{BW}$ intravenously. After 30, 60, and 90 min of the injection, six rats per time-point were anesthetized as before and the carotid bodies dissected out. DA content analysis was performed as for the in vitro experiments. In one control group $(n=6)$, the carotid bodies were dissected immediately after being injected with saline. To take into account variations due to stress after injections, a second group of controls $(n=6)$ were obtained from animals killed $90 \mathrm{~min}$ after the saline injection.

\section{Cell culture and Northern blot analysis}

Cell line PC-12 has been previously characterized as an oxygen-sensing cell line and has been frequently used as a model for carotid body function (Millhorn et al. 1996). This rat cell line was obtained from ATCC (Manassas, VA, USA) and grown in RPMI 1640 medium supplemented with 10\% horse serum and 5\% fetal bovine serum (Life Technologies, Gaithersburg, MD, USA). Freshly fed cells were equally distributed into ten T-175 culture flasks and maintained until 50\% confluent. At this time, five flasks 
were kept under normoxic conditions $\left(20 \% \mathrm{O}_{2}, 5 \% \mathrm{CO}_{2}\right.$, $75 \% \mathrm{~N}_{2}$ ), whereas the other five were subjected to hypoxic conditions $\left(1 \% \mathrm{O}_{2}, 5 \% \mathrm{CO}_{2}, 94 \% \mathrm{~N}_{2}\right)$ in a hypoxia chamber as previously described (Garayoa et al. 2000). Total RNA was extracted at $0,4,8,12$, and $24 \mathrm{~h}$ from both environments using the guanidine isothiocyanate and cesium chloride method. Total RNA $(15 \mu \mathrm{g})$ was loaded per lane in $1 \%$ agarose gels containing $2 \cdot 2 \mathrm{M}$ formaldehyde, blotted by capillarity onto nitrocellulose membranes (Schleicher \& Schuell, Inc., Keene, $\mathrm{NH}$, USA), and baked for $2 \mathrm{~h}$ at $80^{\circ} \mathrm{C}$. Equal loading and integrity of RNA were monitored by ethidium bromide staining of the $18 \mathrm{~S}$ subunit of rRNA.

A rat-specific AM (GenBank accession number U15419) probe was prepared by PCR with primers: sense $\left(\mathrm{rAM}_{43-66}\right) 5^{\prime}$-CTC GGC TTC TCA TCG CAG TCA GTC-3' and antisense $\left(\mathrm{rAM}_{1211-1234}\right)$ 5'-CAC ACG GGG AAC CAA ACA ACC TTA-3'. The 1192 bp PCR product was cloned into pCR II (Invitrogen, Carlsbad, CA, USA) and sequenced to ensure sequence identity. The probe was excised from the vector using EcoRI and labeled with $\left[\alpha_{-}{ }^{32} \mathrm{P}\right] \mathrm{dCTP}(3000 \mathrm{Ci} / \mathrm{mmol}$; NEN Life Science Products, Boston, MA, USA) by random priming and unincorporated nucleotides were removed by Probe-Quant G-50 Micro Columns (Amersham Pharmacia Biotech, Piscataway, NJ, USA). Hybridization was carried out overnight at $42{ }^{\circ} \mathrm{C}$ in a hybridization buffer containing $40 \%$ formamide. After stringency washes, blots were exposed to XAR film (Eastman Kodak, Rochester, NY, USA) at $-80{ }^{\circ} \mathrm{C}$ for varying times. These experiments were repeated three times.

\section{Reverse transcription and real-time PCR}

To quantify variations in the levels of AM mRNA induced by hypoxia, we performed real-time PCR on the same samples analyzed by Northern blotting. Total RNA $(3 \mu \mathrm{g})$ from treated PC-12 cell samples was retrotranscribed in a final volume of $25 \mu \mathrm{l}$ using SuperScript First-Strand Synthesis system (Invitrogen) following the manufacturer's instructions.

The quantitative real-time PCR reaction was run in an Opticon cycler (MJ Research, Waltham, MA, USA) using Sybr Green PCR master mix (Applied Biosystems, Foster City, CA, USA) following the manufacturer's instructions. Thermocycling was performed in a final volume of $25 \mu \mathrm{l}$ containing $2 \mu \mathrm{l}$ cDNA (1:10 dilution) and $400 \mathrm{nM}$ primers (primers for $\mathrm{AM}$ as above or $\beta$-actin forward: $5^{\prime}$-ACA ATG AGC TGC GTG TGG C- $3^{\prime}$, and $\beta$-actin reverse: $5^{\prime}$-TCT CTT TAA TGT CAC GCA CGA-3'). Both $\beta$-actin and AM targets were amplified in triplicates in the same run using the following cycle scheme: after initial denaturation of the samples at $95^{\circ} \mathrm{C}$ for $2 \mathrm{~min}, 40$ cycles of $95{ }^{\circ} \mathrm{C}$ for $30 \mathrm{~s}, 60{ }^{\circ} \mathrm{C}$ for $30 \mathrm{~s}$, and $72{ }^{\circ} \mathrm{C}$ for $45 \mathrm{~s}$ were performed. Fluorescence was measured in every cycle and AM mRNA levels were normalized by the $\beta$-actin values in all samples. A melting curve was run after PCR by increasing the temperature from $50{ }^{\circ} \mathrm{C}$ to $96{ }^{\circ} \mathrm{C}\left(0.5{ }^{\circ} \mathrm{C}\right.$ increments). A single peak was obtained for either $\beta$-actin or AM, thus confirming the specificity of the amplification.

\section{Western blotting}

PC-12 cells were exposed to hypoxia or normoxia for $24 \mathrm{~h}$ in serum-free medium (RPMI 1640 containing $10 \mu \mathrm{g} / \mathrm{ml}$ transferrin, $10 \mu \mathrm{g} / \mathrm{ml}$ insulin, and $50 \mathrm{nM}$ sodium selenite). The supernatants were freeze-dried and resuspended in sample buffer containing $\beta$-mercaptoethanol (Novex, San Diego, CA, USA) and the equivalent of $0.5 \mathrm{ml}$ medium was loaded per well. The cell pellets were sonicated in lysis buffer $(10 \mathrm{mM}$ Tris- $\mathrm{HCl}, \mathrm{pH} 7 \cdot 4,1 \mathrm{mM}$ sodium orthovanadate, and $1 \%$ sodium dodecyl sulfate) and cleared by ultracentrifugation. Protein contents were calculated by the bicinchoninic acid method (Pierce, Rockford, IL, USA) and $25 \mu \mathrm{g}$ total protein was loaded per well. Synthetic AM (3 ng) was loaded in a separate well as a positive control. Samples were electrophoretically separated on NuPage $12 \%$ Bis-Tris gels (Novex), and run at $180 \mathrm{~V}$ until the front dye reached the bottom. Transfer blotting was accomplished in the same apparatus equipped with a titanium plate electrode and transferred to a $0.45 \mu \mathrm{m}$ nitrocellulose membrane at $30 \mathrm{~V}$ for $1.5 \mathrm{~h}$. The membrane was blocked overnight with $5 \%$ non-fat dry milk in phosphate-buffered saline, and incubated for $1 \mathrm{~h}$ in the primary antibody against AM (1:2500). The membrane was further exposed to peroxidase-bound goat anti-rabbit immunoglobulins (Sigma, St Louis, MO, USA), 1:10 000 for another hour, and then peroxidase activity was revealed with the ECL+Plus chemiluminiscence kit (Amersham, Arlington Heights, IL, USA) following the manufacturer's instructions. These experiments were repeated three times.

\section{Statistical analysis}

The averaged media DA release elicited by the two carotid bodies belonging to the same animal was used. The number of animals used for each time-point or treatment was six to eight. Differences between groups were evaluated by one-way analysis of variance followed by Duncan's post hoc test. When only two groups of data were statistically compared, Student's $t$-test was used. $P$ values lower than 0.05 were considered statistically significant.

\section{Results}

Immunohistochemical techniques clearly demonstrated that AM immunoreactivity is present in the carotid bodies, presenting a granular pattern. Using anti-tyrosinehydroxylase as a marker of glomus cells, we found a complete colocalization with AM by confocal microscopy 


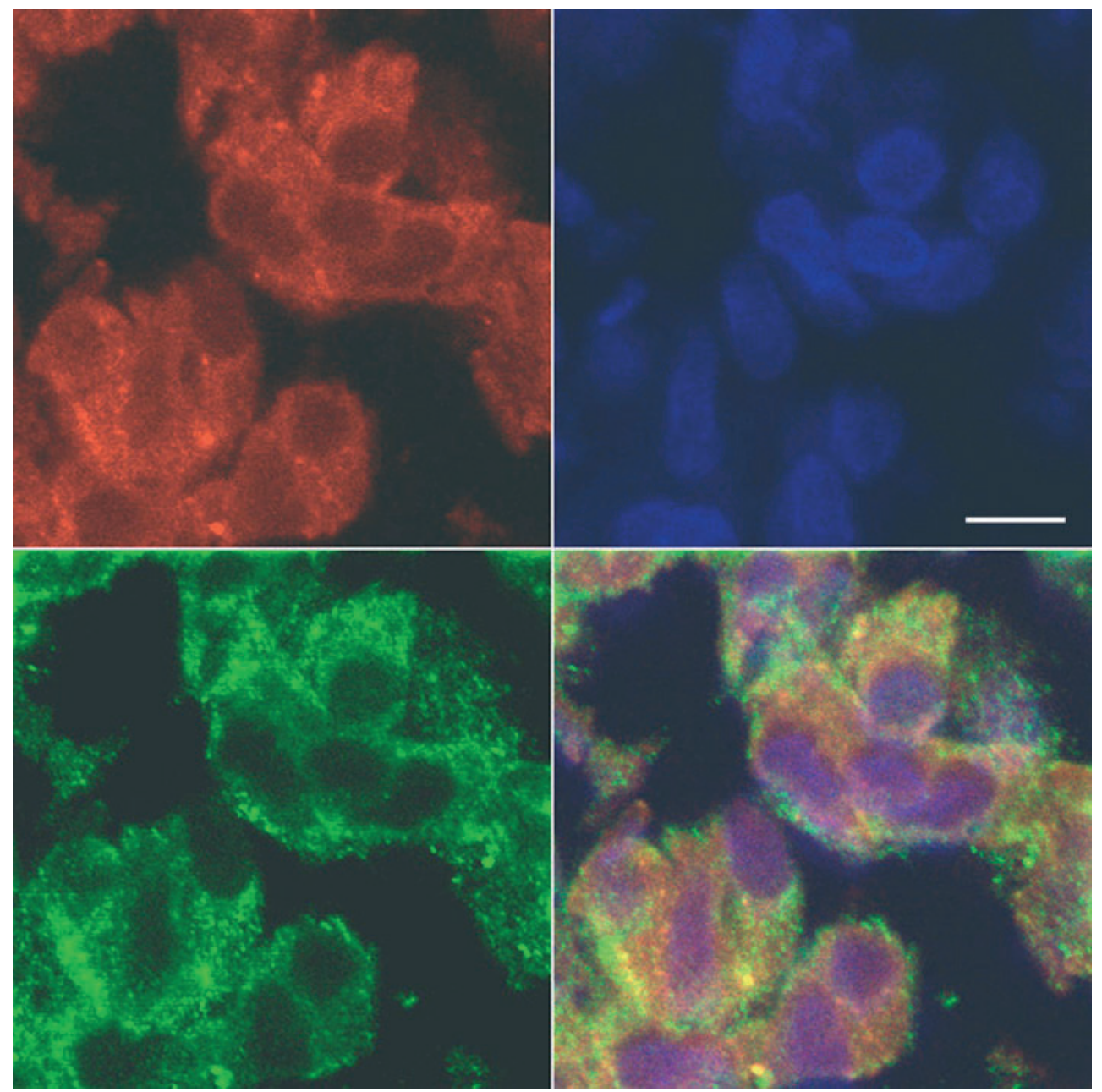

Figure 1 Double immunofluorescence followed by confocal microscopy of a frozen section of a rat carotid body. Tyrosine hydroxylase was demonstrated in red (top left), AM in green (bottom left), and the DNA marker DAPI in blue (top right). The combination of the previous images (bottom right) shows a clear colocalization of tyrosine hydroxylase and AM in the cytoplasm of the glomus cells. Bar $=10 \mu \mathrm{m}$.

(Fig. 1), demonstrating that the glomus cells are the source of the immunoreactive AM in the carotid bodies.

To investigate whether AM influences carotid body function, we incubated freshly isolated rat carotid bodies in the presence of $10^{-6} \mathrm{M}$ AM and measured their DA contents at different times. Basal DA release from carotid bodies was $223 \cdot 6 \pm 27 \cdot 1 \mathrm{pg} / 20 \mu \mathrm{l}$. Addition of $100 \mathrm{mM}$ $\mathrm{KCl}$, a potent secretagogue, evoked a significant $105 \cdot 2 \%$ increase in DA release. By 5 min after AM treatment we had already found a non-statistically significant trend in DA increase, with maximum levels obtained after $30 \mathrm{~min}$. At this time-point, a 94.2\% elevation over basal levels was observed. By 60 min, DA release from the carotid bodies began to decrease. The release of DA at $30 \mathrm{~min}$ after AM treatment was indistinguishable from the values elicited by 5 min exposure to $\mathrm{KCl}$ (Fig. 2).
A dose-dependent response to AM was observed when the carotid bodies were treated for $30 \mathrm{~min}$ with different concentrations of AM (Fig. 3). Concentrations higher than $10^{-6} \mathrm{M}$ AM produced statistically significant increases in DA secretion.

In the in vivo study, DA release from the carotid bodies in control animals was $206 \cdot 1 \pm 36 \cdot 0 \mathrm{pg} / 20 \mu \mathrm{l}$. This value was similar to the release from carotid bodies of rats killed $90 \mathrm{~min}$ after saline injection $(216 \cdot 4 \pm 35 \cdot 4 \mathrm{pg} / 20 \mu \mathrm{l})$ and these two groups were combined as a single control group. Injection of AM in vivo produced an apparent trend towards an increase in DA, although there were no statistically significant differences, with values $263 \cdot 2 \pm 45 \cdot 5,272 \cdot 3 \pm 40 \cdot 2$, and $263 \cdot 1 \pm 51 \cdot 6 \mathrm{pg} / 20 \mu \mathrm{l}$ for 30,60 , and $90 \mathrm{~min}$ after injection respectively. 


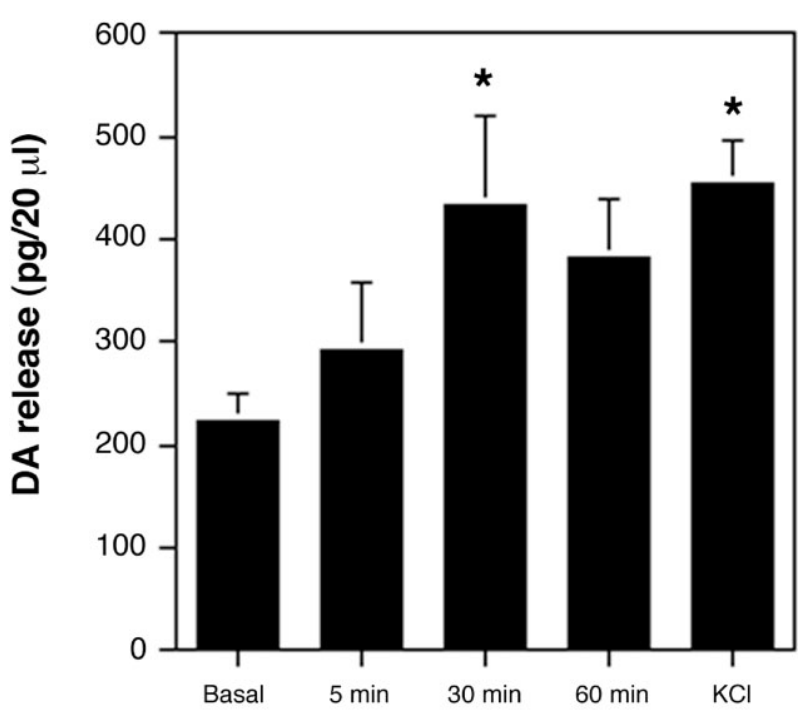

Treatment

Figure 2 DA release, expressed as $\mathrm{pg} / 20 \mu \mathrm{l}$, in freshly isolated carotid bodies exposed to $10^{-6} \mathrm{M} \mathrm{AM}$ for the indicated times. $\mathrm{KCl}$ was added for $5 \mathrm{~min}$ as a positive control. Each bar represents the mean and standard deviation of six to eight animals. The asterisks indicate statistical differences from the basal levels $(P<0 \cdot 05)$.

The cell line PC-12 was used as a model to investigate whether hypoxia induces AM expression and secretion in oxygen-sensitive cells. PC-12 cells cultured under

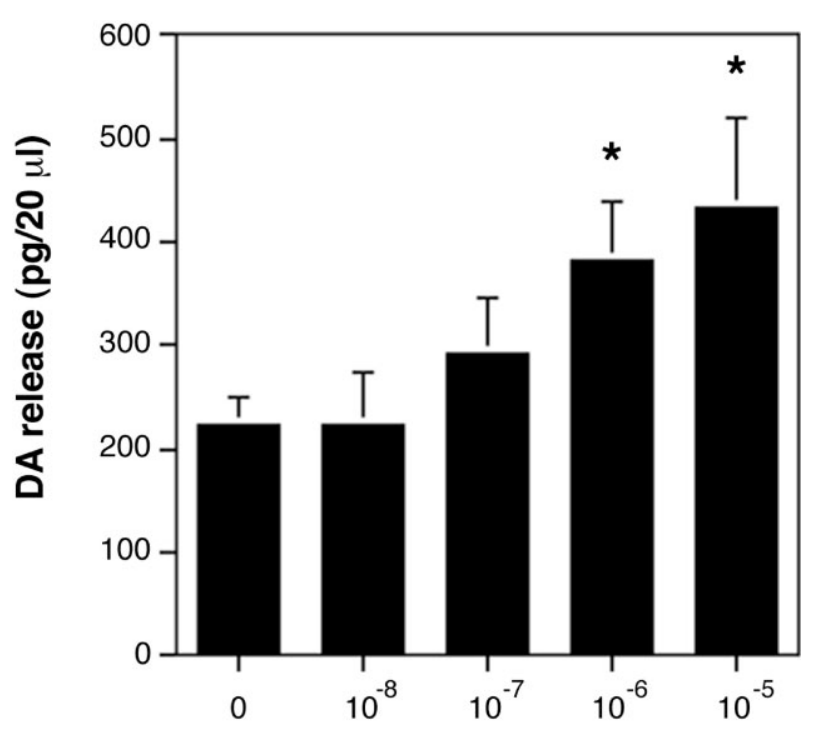

AM addition (M)

Figure 3 DA release (expressed as $\mathrm{pg} / 20 \mu \mathrm{l}$ ) from freshly isolated carotid bodies exposed to increasing concentrations of AM for $30 \mathrm{~min}$. Each bar represents the mean and standard deviation of six to eight animals. The asterisks indicate statistical differences with the basal levels $(P<0 \cdot 05)$. normoxic conditions showed a slight tendency to decrease their AM expression levels over time, as shown by Northern blot analysis (Fig. 4A). On the other hand, when these cells were exposed to hypoxia, a marked elevation of AM mRNA was observed by $4 \mathrm{~h}$, this up-regulation reaching a maximum at $12 \mathrm{~h}$. After $24 \mathrm{~h}$ of hypoxia, the levels of AM mRNA were still much higher than the levels seen in the normoxic cells (Fig. 4).

When the levels of mRNA were quantified by realtime PCR, the trends observed by Northern blotting were confirmed, with statistically higher AM levels seen from $4 \mathrm{~h}$ exposure to hypoxia onwards (Fig. 4B). When including treatment (normoxia vs hypoxia) and time $(0-24 \mathrm{~h}$ ) as factors in an analysis of variance, both factors showed statistically significant differences ( $\mathrm{df} 2, \quad \mathrm{~F}=82.352$, $P<0.001$ for treatments and $\mathrm{df} 4, \mathrm{~F}=26.985, P<0 \cdot 001$ for time). Less significant difference post hoc analysis showed significant differences between treatments at 4,8 , and $24 \mathrm{~h}$ $(P<0 \cdot 001)$.

Western blot analysis showed that after $24 \mathrm{~h}$ exposure to hypoxia, the intracellular contents of AM decreased slightly whereas the amount of AM secreted into the medium increased considerably, suggesting that hypoxia not only increases AM expression but also its release from the secretory granules (Fig. 4C).

\section{Discussion}

The present data demonstrate that AM immunoreactivity is expressed by the glomus cells of the carotid bodies. In addition, AM was shown to modulate carotid body function by inducing DA release in vitro in a time- and dose-dependent manner. Furthermore, we have shown that AM expression and secretion are elevated upon hypoxic exposure in oxygen-sensitive cells. These observations suggest that AM may act as an autocrine regulator of carotid body physiology. The concentration of AM needed to elicit a statistically significant induction of DA release in our experimental model was $10^{-6} \mathrm{M}$. This is also the concentration needed for inducing effects on PC-12 signal transduction pathways through the AM gene-related peptide, proadrenomedullin N-terminal 20 peptide (Takekoshi et al. 1999). These high concentrations may well be accomplished through an autocrine mechanism in the vicinity of the degranulation sites.

In the time-course experiment, statistically significant difference from the basal levels was achieved after $30 \mathrm{~min}$ of incubation, indicating that $\mathrm{AM}$ requires the activation of an intracellular signal transduction pathway rather than acting directly on the membrane potential, as does $\mathrm{KCl}$ which induces a similar response in only $5 \mathrm{~min}$. In addition, the statistically significant difference was lost by 60 min, suggesting that AM may be degraded by components of the carotid body. A rapid degradation of AM has been reported when exposed to cell membranes from different origins (Lewis et al. 1997). 
A
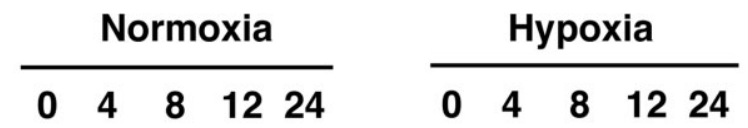

(h)

$1.6 \mathrm{~Kb}-$

18 S rRNA -

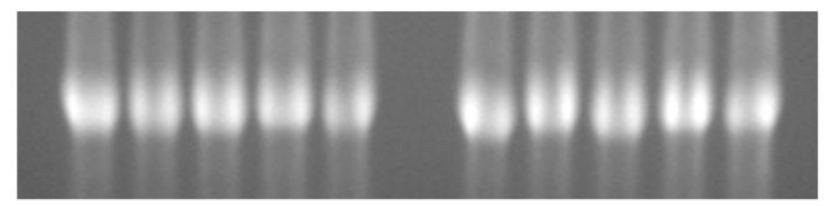

B
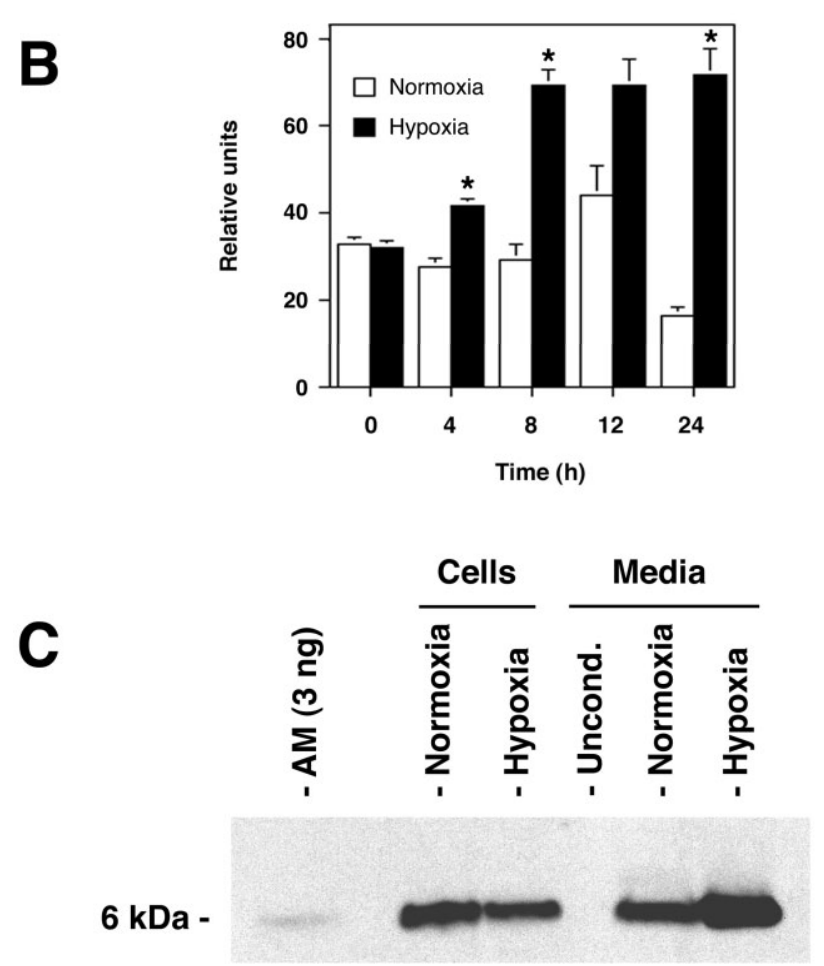

Figure 4 Effects of hypoxia on the expression and secretion of AM from PC-12 cells. (A) Northern blot analysis of PC-12 cells cultured under normoxia or hypoxia for the indicated times. Total RNA $(15 \mu \mathrm{g})$ was loaded per lane and hybridized with a rat-specific AM probe (upper panel). Equal loading was monitored by ethidium bromide staining of $18 \mathrm{~S}$ rRNA (lower panel). (B) The same RNAs were quantified by real-time PCR and corrected by the $\beta$-actin values found in the samples. Statistically significant differences were obtained between treatments in the whole experiment (normoxia vs hypoxia, $P<0 \cdot 001$ ) and at particular time-points, as indicated by asterisks $(P<0 \cdot 001)$. (C) Western blot detecting the levels of immunoreactive AM in cell extracts ( $25 \mu \mathrm{g}$ total protein/lane) and conditioned media (the equivalent of $0.5 \mathrm{ml}$ serum-free medium) of PC-12 cells grown in normoxia or hypoxia for $24 \mathrm{~h}$. Synthetic AM was added (left lane) as a positive control. Unconditioned medium (Uncond.) was added as a negative control. 
In the Western blot experiment we found a decrease in the intracellular immunoreactivity accompanied by an increase in the amount of secreted AM. This observation suggests that hypoxia not only increases AM expression, as previously reported in other systems (Garayoa et al. 2000, Ogita et al. 2001), but it also induces release of the peptide stored in the secretory granules.

The in vivo injection of $1 \mu \mathrm{l} 60 \mathrm{nM}$ AM/g BW did not produce statistically significant differences in the amount of DA liberated from the carotid bodies. This concentration was chosen because it has been previously shown to elicit biological effects in rats (Martínez et al. 1996). The lack of effect may reflect either the need for higher concentrations in the proximity of the carotid bodies or sequestration of the peptide by the AM-binding protein, complement factor $\mathrm{H}$ (Pío et al. 2001).

Oxygen sensing is performed by electrically excitable cells located in chemoreceptor organs. These cells are capable of sensing global $\mathrm{O}_{2}$ tension and produce cardiorespiratory adjustments during hypoxemia. Organs with this ability include carotid and aortic bodies, neuroepithelial bodies in the lung, and potentially adrenal chromaffin cells in the neonate (López-Barneo et al. 2001). The acute response to hypoxia is mediated by oxygensensitive ion channels located in the membrane of the glomus cell. Low oxygen tension induces closure of $\mathrm{K}^{+}$ channels which results in membrane depolarization, $\mathrm{Ca}^{2+}$ influx, transmitter release to the extracellular milieu, and activation of neighbor afferent sensory fibers (LópezBarneo et al. 2001). On the other hand, intermittent or prolonged exposures to hypoxia produce changes in gene expression and tissue remodeling.

Since there are no available cell lines derived from carotid bodies, many studies have employed cells of the adrenal medulla as models, given their common embryological origin from the neural crest and their demonstrated oxygen-sensing capability (Millhorn et al. 1996). Our Northern blot and real-time PCR analysis in PC-12 cells showed that exposure to hypoxia induces overexpression of AM mRNA, with a concomitant increase in the amount of secreted peptide as shown by Western blot analysis of serum-free conditioned medium. Previous studies have shown that addition of extrinsic AM to chromaffin cells stimulates catecholamine release (Kobayashi et al. 2001). Thus, we could hypothesize that a similar mechanism may be at work in the carotid body, with hypoxemia inducing overexpression and secretion of AM, which in turn may collaborate in the release of DA from glomus cells.

Unlike its effects in other organs, hypoxia causes the carotid body to grow by increasing the number, size, and excitability of glomus cells (Stea et al. 1992). These changes are most likely mediated by the transcription factor, HIF-1 (López-Barneo et al. 2001). We have previously demonstrated that $\mathrm{AM}$ is transactivated by HIF-1 under hypoxic conditions (Garayoa et al. 2000) and that $\mathrm{AM}$ is a growth factor for a number of cells of different tissue origins (Miller et al. 1996, Martínez et al. 1997). AM has been also characterized as an antiapoptotic factor (Kato et al. 1997, Martínez et al. 2002). These observations, together with the data presented in this study, indicate that AM may be one of the main intermediaries linking hypoxic stimulus and growth of the carotid body.

An emerging promising therapy for Parkinson's disease is the autotransplant of carotid bodies into the striatum (Espejo et al. 1998, Luquin et al. 1999). The initial hypothesis was to use the cells from the carotid body as sources of DA for the nigro-striatal circuit, which is DA depleted in Parkinson's patients. Nevertheless, careful analysis of the animals receiving the transplants has shown that the newly formed dopaminergic fibers do not arise from the glomus cells but from the substantia nigra. Apparently, the glomus cells secrete a growth factor that induces recovery of the original neural pattern (Toledo-Aral et al. 2002). Hypothetically, AM could be a good candidate for this function given its abundant presence in the carotid body and its characteristics as a potent growth factor (Miller et al. 1996, Martínez et al. 1997). Investigation in this direction merits further attention.

Numerous studies have shown the involvement of AM in regulating blood pressure through both a direct influence in the blood vessels driving vasodilatation (Parkes 1995, Eto et al. 1999, Terata et al. 2000) and in an indirect fashion mediated by the central nervous system, which results in vasoconstriction (Mark et al. 1997, Saita et al. 1998). Here we show a potentially new indirect mechanism of regulating blood flow by eliciting DA release from the carotid bodies. Since DA is a vascular tone modulator (Furukawa et al. 2002), this may constitute a new layer of regulation of blood pressure through AM.

\section{References}

Espejo EF, Montoro RJ, Armengol JA \& López-Barneo J 1998 Cellular and functional recovery of Parkinsonian rats after intrastriatal transplantation of carotid body cell aggregates. Neuron 20 197-206.

Eto T, Kitamura K \& Kato J 1999 Biological and clinical roles of adrenomedullin in circulation control and cardiovascular diseases. Clinical and Experimental Pharmacology and Physiology 26 371-380.

Furukawa S, Nagashima Y, Hoshi K, Hirao H, Tanaka R, Maruo K \& Yamane Y 2002 Effects of dopamine infusion on cardiac and renal blood flow in dogs. Journal of Veterinary Medical Science 64 $41-44$.

Garayoa M, Martínez A, Lee S, Pío R, An WG, Neckers L, Trepel J, Montuenga LM, Ryan H, Johnson R, Gassmann M \& Cuttitta F 2000 Hypoxia-inducible factor-1 (HIF-1) up-regulates adrenomedullin expression in human tumor cell lines during oxygen deprivation: a possible promotion mechanism of carcinogenesis. Molecular Endocrinology 14 848-862.

Hinson JP, Kapas S \& Smith DM 2000 Adrenomedullin, a multifunctional regulatory peptide. Endocrine Reviews 21 138-167.

Kapas S, Martínez A, Cuttitta F \& Hinson JP 1998 Local production and action of adrenomedullin in the rat adrenal zona glomerulosa. Journal of Endocrinology 156 477-484. 
Kato H, Shichiri M, Marumo F \& Hirata Y 1997 Adrenomedullin as an autocrine/paracrine apoptosis survival factor for rat endothelial cells. Endocrinology 138 2615-2620.

Kilts CD, Breese GR \& Mailman RB 1981 Simultaneous quantification of dopamine, 5-hydroxytryptamine and four metabolically related compounds by means of reversed-phase high-performance liquid chromatography with electrochemical detection. Journal of Chromatography 225 437-457.

Kitamura K, Kangawa K, Kawamoto M, Ichiki Y, Nakamura S, Matsuo H \& Eto T 1993 Adrenomedullin: a novel hypotensive peptide isolated from human pheochromocytoma. Biochemical and Biophysical Research Communications 192 553-560.

Kobayashi H, Yanagita T, Yokoo H \& Wada A 2001 Adrenomedullin and proadrenomedullin N-terminal 20 peptide (PAMP) in adrenal chromaffin cells. Peptides 22 1895-1901.

Lewis LK, Smith MW, Brennan SO, Yandle TG, Richards AM \& Nicholls MG 1997 Degradation of human adrenomedullin (1-52) by plasma membrane enzymes and identification of metabolites. Peptides 18 733-739.

López J \& Martínez A 2002 Cell and molecular biology of the multifunctional peptide, adrenomedullin. International Review of Cytology 221 1-92.

López-Barneo J, Pardal R, Ortega-Sáenz P 2001 Cellular mechanisms of oxygen sensing. Annual Reviews of Physiology 63 259-287.

Luquin MR, Montoro RJ, Guillén J, Saldise L, Insausti R, Del Río J \& López-Barneo J 1999 Recovery of chronic Parkinsonian monkeys by autotransplants of carotid body cell aggregates into putamen. Neuron 22 743-750.

Mark AA, Smith PM \& Ferguson AV 1997 Adrenomedullin injection into the area postrema increases blood pressure. American Journal of Physiology 272 R1698-R1703.

Martínez A, Miller MJ, Unsworth EJ, Siegfried JM \& Cuttitta F 1995 Expression of adrenomedullin in normal human lung and in pulmonary tumors. Endocrinology 136 4099-4105.

Martínez A, Weaver C, López J, Bhathena SJ, Elsasser TH, Miller MJ, Moody TW, Unsworth EJ \& Cuttitta F 1996 Regulation of insulin secretion and blood glucose metabolism by adrenomedullin. Endocrinology 137 2626-2632.

Martínez A, Elsasser TH, Muro-Cacho C, Moody TW, Miller MJ, Macri CJ \& Cuttitta F 1997 Expression of adrenomedullin and its receptor in normal and malignant skin: a pluripotential role in the integument. Endocrinology 138 5597-5604.

Martínez A, Vos M, Guédez L, Kaur G, Chen Z, Garayoa M, Pío R, Moody T, Stetler-Stevenson WG, Kleinman HK \& Cuttitta F 2002 The effects of adrenomedullin overexpression in breast tumor cells. Journal of the National Cancer Institute 94 1226-1237.

Miller MJ, Martínez A, Unsworth EJ, Thiele CJ, Moody TW \& Cuttitta F 1996 Adrenomedullin expression in human tumor cell lines: its potential role as an autocrine growth factor. Journal of Biological Chemistry 271 23345-23351.

Millhorn DE, Conforti L, Beitner-Johnson D, Zhu W, Raymond R, Filisko T, Kobayashi S, Peng M \& Genter MB 1996 Regulation of ionic conductances and gene expression by hypoxia in an oxygen sensitive cell line. Advances in Experimental Medicine and Biology 410 $135-142$.
Ogita T, Hashimoto E, Yamasaki M, Nakaoka T, Matsuoka R, Kira Y \& Fujita T 2001 Hypoxic induction of adrenomedullin in cultured human umbilical vein endothelial cells. Journal of Hypertension 19 603-608.

Parkes DG 1995 Cardiovascular actions of adrenomedullin in conscious sheep. American Journal of Physiology 268 H2574-H2578.

Pío R, Martínez A, Unsworth EJ, Kowalak JA, Bengoechea JA, Zipfel PF, Elsasser TH \& Cuttitta F 2001 Complement factor H is a serum binding protein for adrenomedullin. The resulting complex modulates the bioactivities of both partners. Journal of Biological Chemistry 276 12292-12300.

Prabhakar NR, Fields RD, Baker T \& Fletcher EC 2001 Intermittent hypoxia: cell to system. American Journal of Physiology 281 L524-L528.

Rosenblad C \& Nilsson OG 1993 Basal forebrain grafts in the rat neocortex restore in vivo acetylcholine release and respond to behavioural activation. Neuroscience 55 353-362.

Saita M, Shimokawa A, Kunitake T, Kato K, Hanamori T, Kitamura K, Eto T \& Kannan H 1998 Central actions of adrenomedullin on cardiovascular parameters and sympathetic outflow in conscious rats American Journal of Physiology 274 R979-R984.

Serrano J, Uttenthal LO, Martínez A, Fernández AP, Martínez de Velasco J, Alonso D, Bentura ML, Santacana M, Gallardo JR, Martínez-Murillo R, Cuttitta F \& Rodrigo J 2000 Distribution of adrenomedullin-like immunoreactivity in the rat central nervous system by light and electron microscopy. Brain Research $\mathbf{8 5 3}$ 245-268.

Serrano J, Alonso D, Encinas JM, López JC, Fernández AP, Castro-Blanco S, Richart A, Bentura ML, Santacana M, Uttenthal LO, Cuttitta F, Rodrigo J \& Martínez A 2001 Adrenomedullin expression is upregulated by ischemia-reperfusion in the cerebral cortex of the adult rat. Neuroscience 109 717-731.

Stea A, Jackson A \& Nurse CA 1992 Hypoxia and $\mathrm{N}^{6}, \mathrm{O}^{2}$-dibutyryladenosine $3^{\prime}, 5^{\prime}$-cyclic monophosphate, but not nerve growth factor, induce $\mathrm{Na}^{+}$channels and hypertrophy in chromaffin-like arterial chemoreceptors. PNAS 89 9469-9473.

Takekoshi K, Isobe K, Nomura F, Motooka M, Nanmoku T \& Nakai T 1999 Effects of PAMP on mRNA coding for catecholaminesynthesizing enzymes in PC12 cells. Life Sciences 65 771-781.

Terata K, Miura H, Liu Y, Loberiza F \& Gutterman DD 2000 Human coronary arteriolar dilation to adrenomedullin: role of nitric oxide and $\mathrm{K}(+)$ channels. American Journal of Physiology 279 H2620-H2626.

Toledo-Aral JJ, Méndez-Ferrer S, Pardal R \& López-Barneo J 2002 Dopaminergic cells of the carotid body: physiological significance and possible therapeutic applications in Parkinson's disease. Brain Research Bulletin 57 847-853.

Verbiese-Genard N, Hanocq M, Alvoet C \& Molle L 1983 Degradation study of catecholamines, indolamines and some of their metabolites in different extraction media by chromatography and electrochemical detection. Analytical Biochemistry 134 170-175.

Received in final form 9 September 2002 Accepted 24 September 2002 